\title{
Dissecting Export Trade Patterns of Georgian Economy and the Growing Importance of the European Union Market
}

\section{Davit Belkania}

PhD, Kaposvár University, Faculty of Economic Science

\section{Abstract}

From the very beginning of its rebirth after leaving the Soviet Union, Georgia embarked on a transition to a free market economy and linked its fate to western culture. Since then, strengthening the private sector, creating an attractive investment climate, promoting trade liberalization and above all else fostering exports are the main concerns of the country. Thus, as an export-oriented country, close examination of the Georgian export performance is of great importance. Besides the decomposition of general export trends for the period of 2008-2017, this paper applies Balassa index of revealed comparative advantage (RCA) to identify the key export sectors with comparative advantage and correspondingly with higher growth potential; By this shaping the export promotion policy to prioritize those sectors as the main drivers to increase export earnings. Furthermore, the study employed export product diversification index to gauge the convergence degree of Georgian exports structure by products to the structure of the world; as it significantly affects the resistance of a country towards the trade shocks caused by a price instability of the exported commodities. Eventually, the EUGeorgia trade relationship will be assessed through the trade intensity index to check whether the value of trade between the EU and Georgia is corresponding to the expectations based on their importance in world trade. The results show the comparative advantage for nine products (HS4) that account for $<60 \%>$ of total exports including all the major sectors of Georgian export production. The diversification degree of export products improved over the last decade but still very poor, thus, it is unlikely for Georgia to resist the external trade shocks in case of a price instability of the exported commodities. Furthermore, despite the removal of the main trade barriers between EU and Georgia, it appears that the bilateral trade relationship is characterized by a low-intensity pattern, meaning that there is much to trade between the partners. The problem of low-intensity can be linked to the lack 
of accessible export-related information that limits the ability of the new entrants to survive. As a result, discouragement of new firms to become exporters limits the diversification of export basket, which in turn negatively affects the level of trade intensity between the trade partners and decreases the potential trade benefits of bilateral agreements.

Keywords: RCA index, export, trade intensity, Georgia

\section{Introduction}

Globalization along with internationalization of an economy is quite handy when it comes to economic development. It can complement economic development through increased trade benefits and foreign direct investment (FDI) inflow, technology spillover, and economies of scale. In this regard, the globalization of Georgia concerning the European integration process is not an exception. It is acknowledged that the coherence with EU will prompt competitive pressure for Georgian export production, but at first glance, due to the factor endowments, attractive investment climate and the untapped potential of Georgian agricultural sector, it should be the least ofa concern. Located at the crossroads of two biggest markets, namely Europe and Asia, Georgia has a capacity to develop into the intercontinental hub and fuel its economy through the export earnings.

As a newborn market economy, Georgia has a substantial base to be a competitive actor in the international market. After engaging in trade agreements with world trade organization (WTO) in 2000 and European Union (EU), which granted Georgia with Generalized System of Preferences (GSP+) and Deep and Comprehensive Free Trade Area (DCFTA), Georgian export products exhibit growing heterogeneity. Thus, suggesting that openness to an international market can enhance the degree of product diversification by this enhancing the export earnings and correspondingly the economic growth. As a whole, theoretical background along with the economic bases developed by the country during its transition process suggests the rapid growth effect on the economy. Unfortunately, the export performance of Georgia does not indicate the presumed growth effect. Thus, Georgian exports require delicate observation to identify pros and cons regarding export production by this shedding the light on the modest performance of the country in the international market. In addition, EU, as the new dimension of Georgian export market which accounts for $24 \%$ share of total export, needs further exploration and should be treated exceptionally to reap the maximum trade benefits.

\section{Methodology}

This paper examines the general trends of the Georgian export trade along with the growth potential of its export production in an international market, diversification degree of the products and the trade intensity with European Union (EU) as the latest 
addition to the Georgian export market. Hence, following trade indices were employed: Balassa index of the revealed comparative advantage (RCA), Diversification degree of export products and the trade intensity indices (TII). Twenty product categories were examined for the period of 2008-2017. The data was collected from the International Trade Center (ITC) agency and the United Nations Conference on Trade and Development (UNCTADSTAT) database.

\subsection{Balassa index of revealed comparative advantage (RCA)}

The application of the RCA index by Balassa is useful to calculate the relative advantage of Georgia in a particular group of products. It helps us to evaluate the potential of the country's export production by revealing competitive product groups that can be traded with its partners. If certain countries have the indistinguishable RCA index values, then it is unlikely for them to engage in bilateral trade agreements except if a similar-similar trade along with the increasing returns to scale takes place. Mathematical formulation of the Balassa index can be written as follows:

$R C A_{i c}=\left(X_{i c} / X_{i}\right) /\left(X_{c w} / X_{w}\right)$.

Where $R C A_{i c}$ is the Balassa index of the revealed comparative advantage of product $c$ for country $i$, in our case Georgia, $X_{i c}$ is the Georgian export of the product $c, X_{i}$ is the total amount of Georgian exports, $X_{c w}$ is the world export of the product $c$, and $X_{w}$ is the total world exports. Comparative advantage in a particular product or a sector is revealed if the value of the RCA index is more than one.

\subsection{Diversification index of export products}

The diversification index of export products measures the divergence of a certain country's export structure from the world structure. It is an important measure for many developing countries, since the most of them are highly dependent on the limited number of primary commodities, and in case of price instability of these commodities, developing countries can be a subject of serious trade shocks. Thus, increasing the level of the export diversification enables the developing countries to resist external trade shocks. Mathematical formulation of the export diversification index can be written as follows:

$S_{j}=\frac{\sum_{i}\left|h_{i j}-h_{i}\right|}{2}$

Where $h_{i j}$ is the share of product $i$ in the total exports of a country $j$ and $h_{i}$ is the share of the product $i$ in the total world exports. The value of the index ranges from 0 to 1 . The value closer to 1 indicates the greater divergence from the world pattern.

\subsection{Trade intensity indices}

The trade intensity index (TII) identifies the degree to which trade partners are engaged in trade with each other. In other words, it is the share of a country's exports going to a partner divided by the share of the world exports going to the partner, thus, 
bilateral trade flow is higher than expected, if the value of the index is more than one. ${ }^{1}$ Mathematical formulation of export/import trade intensity indices of Georgia with the EU is written as follows:

$E x I I_{i j t}=\left(E x_{i j} / E x_{i}\right) /\left(\operatorname{Im}_{j} /\left(\operatorname{Im}_{w}-\operatorname{Im}_{i}\right)\right)$

(3) Export intensity index

Where ExII $I_{i j t}$ is the export intensity index of Georgia with EU at time $t, E x_{i j}$ is the Georgian exports to EU, $E x_{i}$ is the total Georgian exports, $\mathrm{Im}_{j}$ is the total EU imports, $I m_{w}$ is the total world imports, $I m_{i}$ is the total Georgian imports, and $t$ is the time from 2008 to 2017.

$\operatorname{ImII}_{i j t}=\left(\operatorname{Im}_{i j} / \operatorname{Im}_{i}\right) /\left(E x_{j} /\left(E x_{w}-E x_{i}\right)\right)$

(4) Import intensity index

Where $\operatorname{ImII}_{i j t}$ is the import intensity index of Georgia with EU at time $t, \operatorname{Im}_{i j}$ is the imports of Georgia from EU, $\operatorname{Im}_{i}$ is the total Georgian imports, $E x_{j}$ is the total EU exports, $E x_{w}$ is the total world exports, $E x_{i}$ is the total Georgian exports, and $t$ is the time span.

\section{Decomposition of Georgian export market}

\subsection{Export trade trends}

Within the last decade, Georgian exports increased by $54.66 \%$ and total external trade turnover by $26.91 \%$. The average total export is 2.168 billion USD. Correspondingly, from 2011 Georgia has been exported over its mean value except for 2016. The annual growth rate exhibits high fluctuation but averaged to positive $10.73 \%$. As for, the export share to GDP, it has increased steadily from 28.62 to 50.41 (See Graph 1).

\section{Graph 1. Total Exports, Average Annual Growth Rate \& Mean Value of Total Exports (2008-2017).}

\section{Total Exports, Export Share to GDP \& Mean Value of Total Exports (2008-2017)}

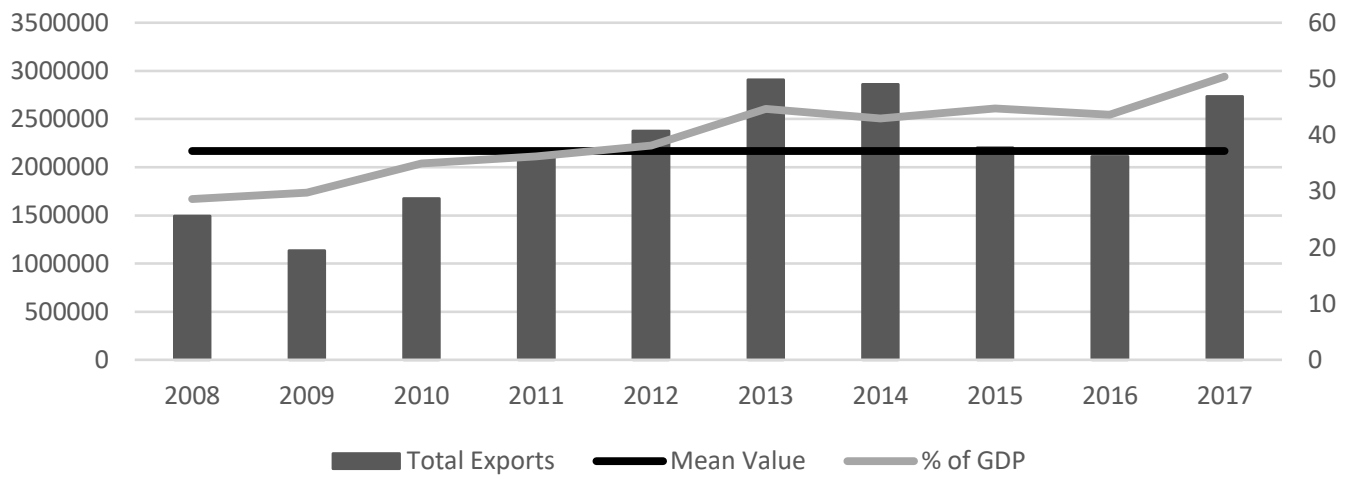

1 Trade indicators: Trade Intensity Index. World Bank Group.

https://wits.worldbank.org/wits/wits/witshelp/Content/Utilities/e1.trade_indicators.htm 
Source: National Statistics Office of Georgia; Authors own calculation

\subsection{Trade structure by partner and product categories}

Top export markets and their average share in total exports during 2008-2017 are as follows: European Union (21.87\%), Commonwealth of Independent States (43.69\%), Black Sea Economic Cooperation Organization (55.34\%), Organization of Economic Cooperation and Development (37.13\%) and GUAM countries (22.23\%) (See Table 1).

Table 1. Top export markets by country groups and their export value in thousand USD alongside average share (\%) in total exports (2008-2017).

\begin{tabular}{|l|l|l|l|l|l|l|}
\hline Year & EU & CIS & BSEC & OECD & GUAM & Total \\
\hline \multirow{2}{*}{2008} & 335.153. & 540.884. & 884.007. & 749.559. & 338.714. & 1.495 .34 \\
& 8 & 8 & 9 & 2 & 6 & 5.2 \\
\hline \multirow{2}{*}{2009} & 237.552. & 416.162. & 697.234. & 519.616. & 251.184. & 1.133 .63 \\
& 5 & 3 & 1 & 5 & 6 & 0.2 \\
\hline \multirow{2}{*}{2010} & 309.189. & 676.618. & 898.098. & 742.692. & 374.325. & 1.677 .30 \\
& 5 & 2 & 3 & 0 & 9 & 6.9 \\
\hline \multirow{2}{*}{2011} & 424.448. & 1.052 .10 & 1.182 .84 & 814.807. & 577.233. & 2.186 .42 \\
& 1 & 1.3 & 3.5 & 3 & 6 & 1.2 \\
\hline \multirow{2}{*}{2012} & 352.950. & 1.244 .57 & 1.326 .38 & 796.116. & 805.398. & 2.376 .63 \\
& 4 & 5.8 & 2.7 & 4 & 3 & 5.4 \\
\hline \multirow{2}{*}{2013} & 607.204. & 1.621 .09 & 1.778 .14 & 841.524. & 917.066. & 2.910 .31 \\
& 0 & 5.7 & 4.4 & 7 & 8 & 4.5 \\
\hline \multirow{2}{*}{2014} & 624.201. & 1.465 .29 & 1.676 .75 & 943.526. & 689.105. & 2.861 .04 \\
& 4 & 8.7 & 8.4 & 1 & 1 & 5.2 \\
\hline \multirow{2}{*}{2015} & 645.214. & 840.936. & 1.089 .22 & 769.200. & 307.361. & 2.204 .68 \\
& 1 & 6 & 9.4 & 7 & 3 & 5.3 \\
\hline \multirow{2}{*}{2016} & 565.531. & 737.522. & 967.355. & 737.263. & 227.738. & 2.112 .92 \\
& 0 & 4 & 2 & 1 & 7 & 2.0 \\
\hline \multirow{2}{*}{2017} & 655.124. & 1.184 .75 & 1.489 .79 & 784.293. & 399.930. & 2.735 .49 \\
& 9 & 8.1 & 9.3 & 6 & 7 & 5.4 \\
\hline Av. & 21.87267 & 43.69845 & 55.34290 & 37.13528 & 22.23512 & \\
Share & 15 & 86 & 24 & 78 & 92 & \\
\hline
\end{tabular}

Currently, one of the main concern of Georgia is the market penetration strategy regarding the EU as it represents the second largest export market for the country. The Association Agreement (AA) including Deep and Comprehensive Free Trade Area (DCFTA) prompted the dynamic increase in the value of Georgian exports to the EU, which doubled from 335.15 to 655.12 million USD with the market share of $23.94 \%$ at the end of 2017 (See Graph 2). 
Graph 2. EU market value in thousand USD and the share (\%) in Georgian export.

EU Market Value (1000 USD) and the market share (\%) in Georgian export

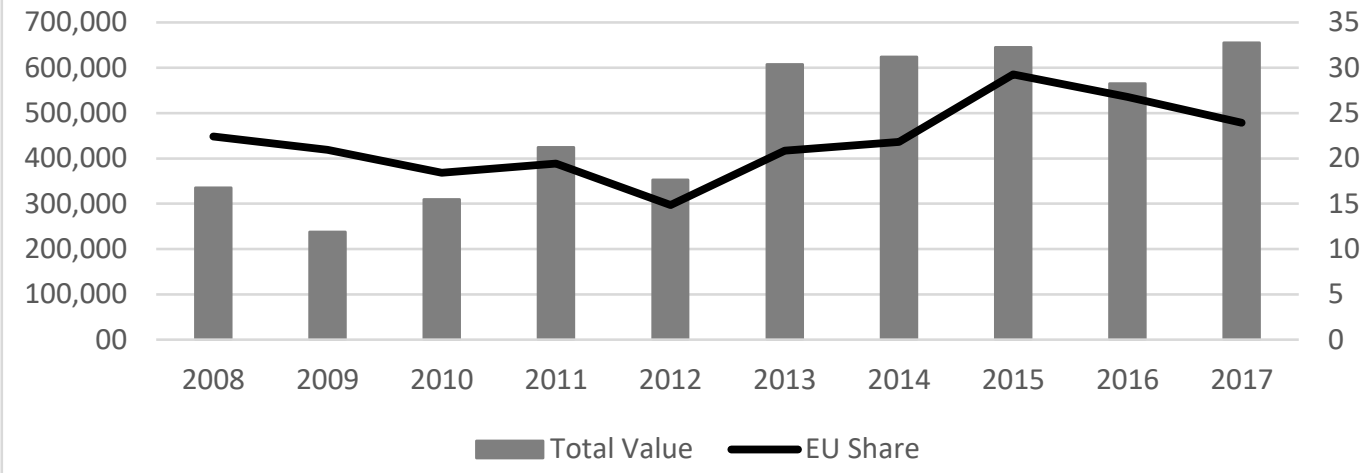

Source: National Statistics Office of Georgia; Authors own calculation

Top Georgian export products and the percentage change in the share of total export from 2008 to 2017 are as follows: Wine $(+3.8 \%)$, copper ores $(+7.49 \%)$, motor cars $(+1.04)$, ferro-alloys $(-6.59 \%)$, beverages, spirits $(+6.05)$. Therefore, Table 2 exhibits the dynamic increase in all major product categories except the ferro-alloys $(-6.59 \%)$ (See Table 2).

Table 2. Value of top Georgian export product categories in thousand USD and their \% change in the export market share (2008-2017).

\begin{tabular}{|l|l|l|l|l|l|}
\hline Year & Wine & $\begin{array}{l}\text { Copper } \\
\text { Ores }\end{array}$ & $\begin{array}{l}\text { Motor } \\
\text { Cars }\end{array}$ & $\begin{array}{l}\text { Ferro- } \\
\text { Alloys }\end{array}$ & Beverages \\
\hline 2008 & 36863 & 118265 & 113324 & 267242 & 138444 \\
\hline 2009 & 31997 & 61868 & 78462 & 130081 & 123776 \\
\hline 2010 & 41138 & 74504 & 227360 & 263966 & 152097 \\
\hline 2011 & 54086 & 85135 & 450297 & 253617 & 192122 \\
\hline 2012 & 64828 & 53535 & 587296 & 260578 & 233129 \\
\hline 2013 & 128299 & 161633 & 703817 & 230748 & 356785 \\
\hline 2014 & 180402 & 248008 & 517787 & 285806 & 444869 \\
\hline 2015 & 95796 & 270601 & 179646 & 194766 & 263850 \\
\hline 2016 & 113497 & 311703 & 166634 & 169265 & 299824 \\
\hline 2017 & 170985 & 419805 & 234885 & 306932 & 417279 \\
\hline $\begin{array}{l}\text { \% Change in } \\
\text { Export } \\
\text { Share }\end{array}$ & 3.8062006 & 7.4913745 & 1.0426459 & - & 6.5947337 \\
\hline
\end{tabular}




\subsection{Demand side of Georgian export commodities in the world and EU area}

Top Georgian export products include wine, copper ores, motor cars, ferro-alloys, beverages, and spirits (See Table 2). The aggregate demand for these commodities in the world/EU area seems to be highly inconsistent. However, it experienced a noticeable increment considering the overall performance from 2007 to 2017 (See Graph 3 \& Graph 4).

According to Graph $3 \& 4$, the structure of the top imported products by the EU area and the world is perfectly matched. The top 10 imported products by HS4 products classification mostly consists of manufactured products like electronic machinery and equipment, vehicles, mechanical appliances, etc. As so, structural coherence of the main Georgian export products with the top imported products by the EU/World is far from perfect. However, convergence is held in terms of motor cars and pharmaceutical products.

\section{Graph 3. Top 10 world import products (HS4) in trillion USD.}

\section{Top 10 world imports (Trillion USD)}

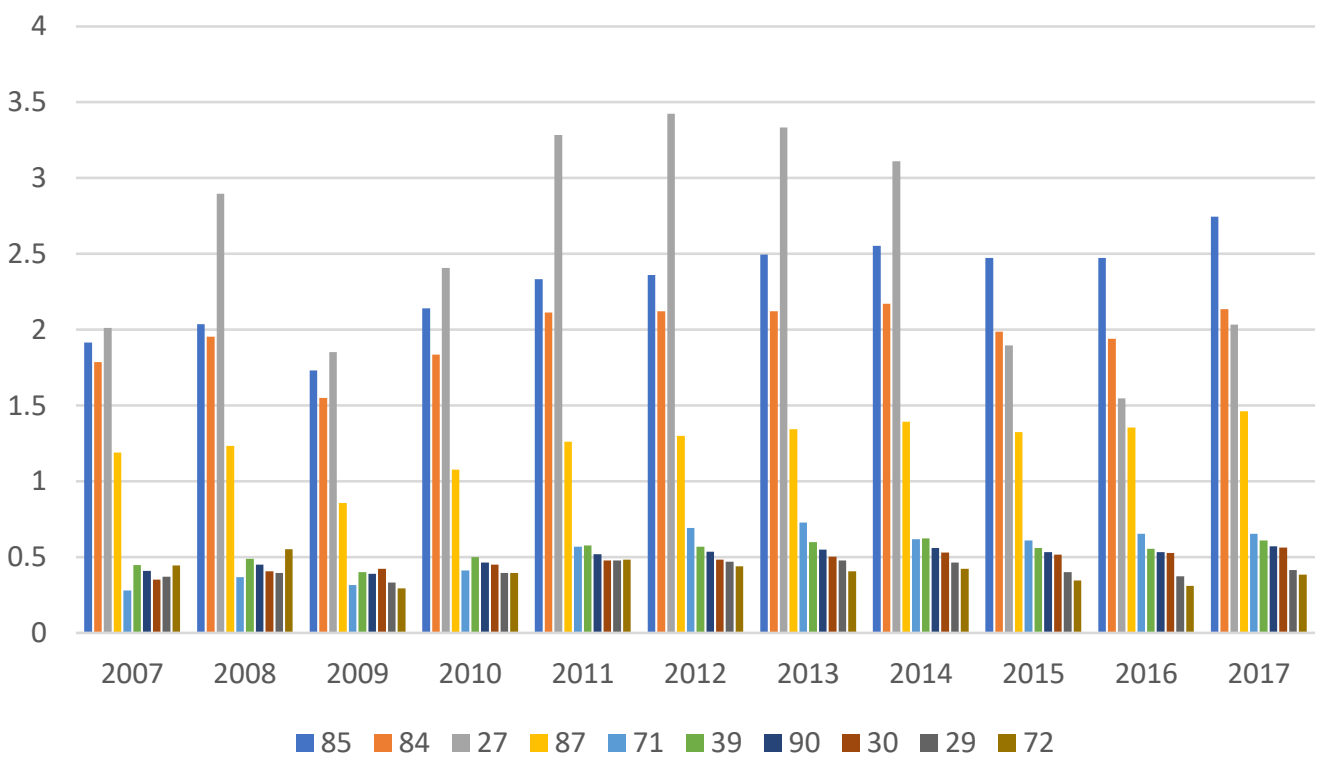

Top 10 world import products by HS4 classification and their corresponding product codes: (85) Electrical machinery and equipment and parts, (84) machinery, mechanical appliances, nuclear reactors, boilers, (27) mineral fuels, mineral oils and products of their distillation; bituminous substances, (87) vehicles other than railway or tramway rolling stock, (71) natural or cultured pearls, precious or semi-precious stones, precious metals, (39) plastics and articles, (90) optical, photographic, 
cinematographic, measuring, checking, precision, medical, (30) pharmaceutical products (29) organic chemicals, (72) iron and steel.

Source: International Trade Centre; Authors own calculation

Graph 4. Top 10 import products (HS4) by EU 28 (Billion USD).

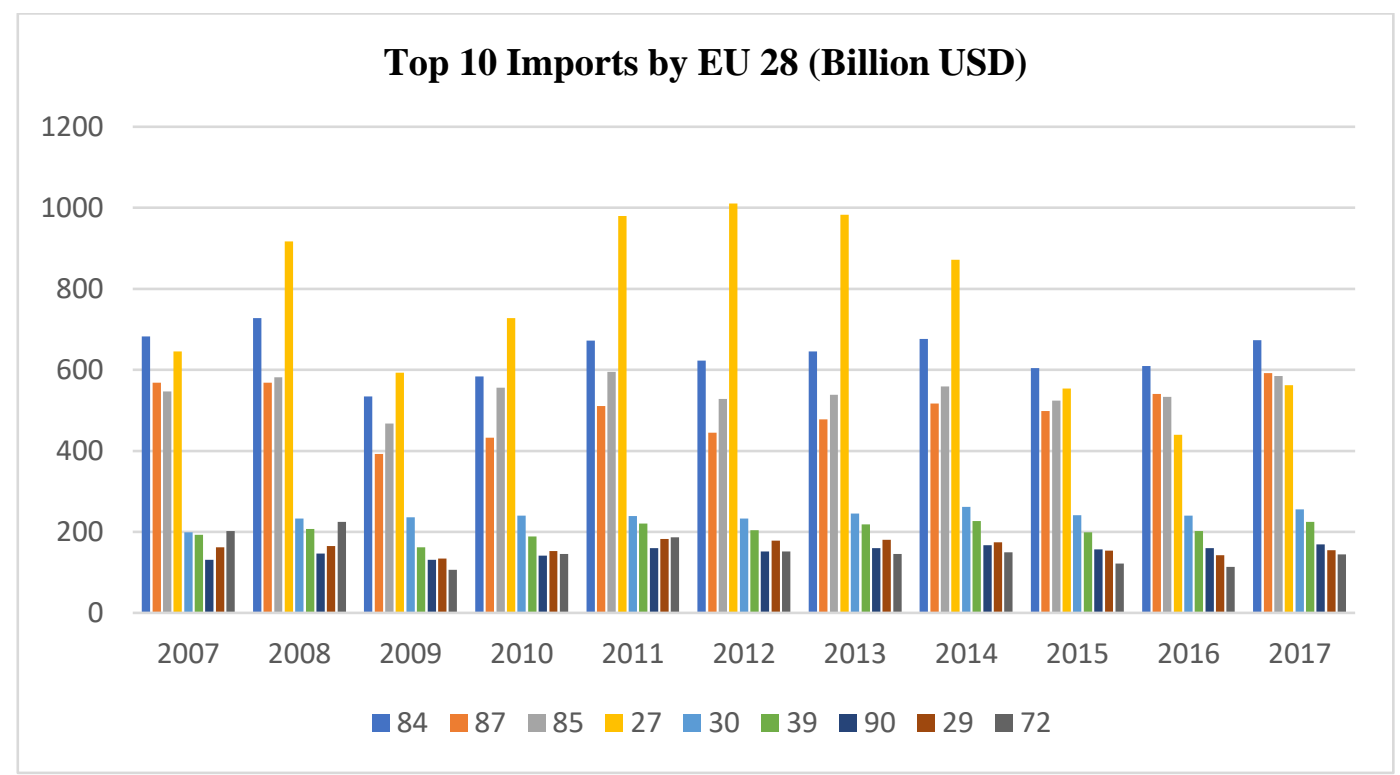

Top 10 EU import products by HS4 classification and their corresponding product codes: (84) Machinery, mechanical appliances, nuclear reactors, boilers, (87) vehicles other than railway or tramway rolling stock, and parts and accessories, (85) electrical machinery and equipment, (27) mineral fuels, mineral oils and products of their distillation; bituminous substances; mineral waxes, (30) pharmaceutical products, (39) plastics and articles, (90) optical, photographic, cinematographic, measuring, checking, precision, medical or surgical, (29) organic chemicals, (72) iron and steel.

Source: International Trade Centre; Authors own calculation

\subsection{Trade indices}

\subsubsection{Revealed comparative advantage}

Application of the RCA index helps us to reveal the portion of a country's export production that exhibits a relative advantage in a market. Accordingly, this paper examined 20 product categories including Wine, Copper ores, Motor cars, Ferroalloys, Live animals, Pharmaceutical products, Beverages, spirits, Vegetable plaiting materials, Edible fruit and nuts, Mineral fuels, Sugars, and sugar confectionery, Preparations of meat, of fish or of crustaceans, mollusks or other aquatic invertebrates, Animal or vegetable fats, and oils and their cleavage products; prepared edible fats; animal or vegetable waxes, Lac; gums, resins and other 
vegetable saps and extracts, Edible vegetables and certain roots and tubers, Live trees and other plants; bulbs, roots and the like; cut flowers and ornamental foliage, Products of animal origin, Dairy produce; birds' eggs; natural honey; edible products of animal origin, Fish and crustaceans, mollusks and other aquatic invertebrates, Meat and edible meat offal.

The results revealed the comparative advantage in 9 product categories, including: Live animals (L.A.), Pharmaceutical products (P.P.), Vegetable plaiting materials (V.P.M.), Edible fruit and nuts (E.F.N.) alongside top 5 Georgian export products, namely: Wine (W.), Copper ores (C.O.), Motor cars (M.C.), Ferro-alloys (F.A.) Beverages and spirits (B.S.).

Table 3. RCA index of 9 Georgian export product categories (2008-2017).

\begin{tabular}{|c|c|c|c|c|c|c|c|c|c|c|}
\hline $\begin{array}{l}\text { Yea } \\
\mathrm{r}\end{array}$ & W. & C. 0. & $\begin{array}{l}\text { M. } \\
\text { C. }\end{array}$ & F.A. & L.A. & $\begin{array}{l}\text { P.P } \\
.\end{array}$ & B.S. & $\begin{array}{l}\text { V.P. } \\
\text { M. }\end{array}$ & $\begin{array}{l}\text { E.F. } \\
\text { N. }\end{array}$ & $\begin{array}{l}\% \\
\text { Chan } \\
\text { ge in } \\
\text { RCA }\end{array}$ \\
\hline $\begin{array}{l}200 \\
8\end{array}$ & $\begin{array}{l}13.1 \\
3\end{array}$ & $\begin{array}{l}37.5 \\
2\end{array}$ & $\begin{array}{l}1.9 \\
0\end{array}$ & $\begin{array}{l}79.5 \\
4\end{array}$ & 1.01 & $\begin{array}{l}0.6 \\
4\end{array}$ & $\begin{array}{l}16.1 \\
7\end{array}$ & 3.00 & 6.54 & 137.2 \\
\hline $\begin{array}{l}200 \\
9\end{array}$ & $\begin{array}{l}13.6 \\
1\end{array}$ & $\begin{array}{l}21.4 \\
4\end{array}$ & $\begin{array}{l}1.9 \\
6\end{array}$ & $\begin{array}{l}87.1 \\
8\end{array}$ & $\begin{array}{l}21.1 \\
9\end{array}$ & $\begin{array}{l}0.6 \\
6\end{array}$ & $\begin{array}{l}16.9 \\
1\end{array}$ & 0.92 & $\begin{array}{l}14.3 \\
1\end{array}$ & 23.6 \\
\hline $\begin{array}{l}201 \\
0\end{array}$ & $\begin{array}{l}13.2 \\
3\end{array}$ & $\begin{array}{l}14.8 \\
4\end{array}$ & $\begin{array}{l}3.6 \\
8\end{array}$ & $\begin{array}{l}88.2 \\
7\end{array}$ & $\begin{array}{l}15.9 \\
3\end{array}$ & $\begin{array}{l}0.7 \\
5\end{array}$ & $\begin{array}{l}15.7 \\
3\end{array}$ & 0.84 & $\begin{array}{l}11.0 \\
8\end{array}$ & 6.5 \\
\hline $\begin{array}{l}201 \\
1\end{array}$ & $\begin{array}{l}13.5 \\
9\end{array}$ & $\begin{array}{l}13.8 \\
1\end{array}$ & $\begin{array}{l}5.8 \\
4\end{array}$ & $\begin{array}{l}66.4 \\
1\end{array}$ & $\begin{array}{l}17.0 \\
1\end{array}$ & $\begin{array}{l}0.7 \\
9\end{array}$ & $\begin{array}{l}15.2 \\
4\end{array}$ & 0.38 & $\begin{array}{l}13.2 \\
6\end{array}$ & -5.9 \\
\hline $\begin{array}{l}201 \\
2\end{array}$ & $\begin{array}{l}15.0 \\
9\end{array}$ & 8.19 & $\begin{array}{l}6.9 \\
8\end{array}$ & $\begin{array}{l}69.3 \\
2\end{array}$ & $\begin{array}{l}20.2 \\
7\end{array}$ & $\begin{array}{l}0.9 \\
1\end{array}$ & $\begin{array}{l}16.8 \\
1\end{array}$ & 1.37 & 8.31 & $\begin{array}{l}1162 . \\
8\end{array}$ \\
\hline $\begin{array}{l}201 \\
3\end{array}$ & $\begin{array}{l}23.8 \\
7\end{array}$ & $\begin{array}{l}19.8 \\
0\end{array}$ & $\begin{array}{l}6.7 \\
4\end{array}$ & $\begin{array}{l}61.2 \\
2\end{array}$ & $\begin{array}{l}17.8 \\
4\end{array}$ & $\begin{array}{l}0.7 \\
8\end{array}$ & $\begin{array}{l}20.3 \\
9\end{array}$ & 0.67 & $\begin{array}{l}12.5 \\
9\end{array}$ & 192.6 \\
\hline $\begin{array}{l}201 \\
4\end{array}$ & $\begin{array}{l}34.2 \\
0\end{array}$ & $\begin{array}{l}31.2 \\
3\end{array}$ & $\begin{array}{l}4.8 \\
2\end{array}$ & $\begin{array}{l}69.3 \\
7\end{array}$ & $\begin{array}{l}13.9 \\
6\end{array}$ & $\begin{array}{l}1.3 \\
5\end{array}$ & $\begin{array}{l}25.8 \\
5\end{array}$ & 0.76 & $\begin{array}{l}12.8 \\
5\end{array}$ & 44.3 \\
\hline $\begin{array}{l}201 \\
5\end{array}$ & $\begin{array}{l}22.3 \\
7\end{array}$ & $\begin{array}{l}43.9 \\
0\end{array}$ & $\begin{array}{l}1.9 \\
7\end{array}$ & $\begin{array}{l}69.0 \\
4\end{array}$ & $\begin{array}{l}14.3 \\
0\end{array}$ & $\begin{array}{l}2.3 \\
2\end{array}$ & $\begin{array}{l}18.7 \\
2\end{array}$ & 1.62 & $\begin{array}{l}14.2 \\
5\end{array}$ & -91.7 \\
\hline $\begin{array}{l}201 \\
6\end{array}$ & $\begin{array}{l}26.2 \\
6\end{array}$ & $\begin{array}{l}49.7 \\
5\end{array}$ & $\begin{array}{l}1.7 \\
9\end{array}$ & $\begin{array}{l}66.2 \\
6\end{array}$ & $\begin{array}{l}16.9 \\
2\end{array}$ & $\begin{array}{l}1.8 \\
1\end{array}$ & $\begin{array}{l}21.0 \\
9\end{array}$ & 1.60 & $\begin{array}{l}13.5 \\
9\end{array}$ & -10.1 \\
\hline $\begin{array}{l}201 \\
7\end{array}$ & $\begin{array}{l}31.1 \\
4\end{array}$ & $\begin{array}{l}46.3 \\
9\end{array}$ & $\begin{array}{l}2.0 \\
2\end{array}$ & $\begin{array}{l}74.8 \\
3\end{array}$ & $\begin{array}{l}12.8 \\
1\end{array}$ & $\begin{array}{l}1.8 \\
7\end{array}$ & $\begin{array}{l}23.3 \\
4\end{array}$ & 0.25 & 5.88 & 137.2 \\
\hline
\end{tabular}

As for Pharmaceutical products, it reveals the comparative advantage after 2013, and the Vegetable plaiting materials exhibit inconsistence tendency (See Table 3). In addition, although the RCA values of Vegetable plaiting materials and Edible fruit and nuts decreased significantly, they maintained the comparative advantage. In general, all 9 product categories account for $60 \%$ of total Georgian export production (See Graph 5). 


\section{Graph 5. The share of 9 Product Categories with RCA $>1$ in Total Export.}

\section{Share of 9 Product Categories with RCA $>1$ in Total ExportShare of 9 Product Categories with RCA $>1$ in Total Export}

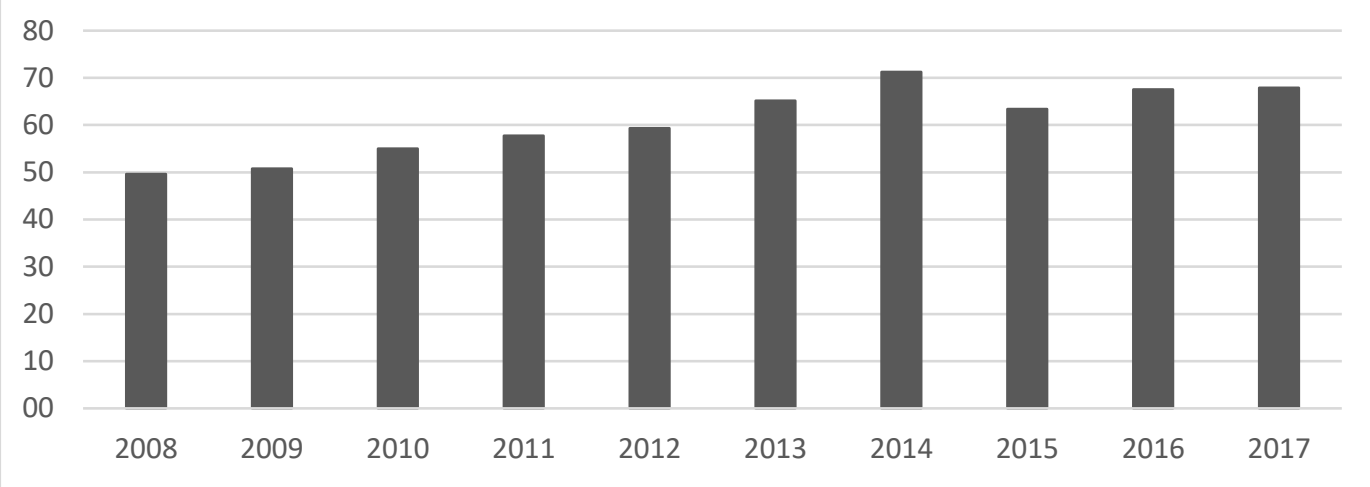

Source: Authors own calculation

The observed RCA values show the growing tendency for all the product categories except Vegetable plaiting materials, Edible fruit and nuts, and Ferro-alloys. According to the Table 3, following changes were detected regarding RCA index: Live animals $(+1162.8 \%)$, Pharmaceutical products $(+192.6 \%)$, Vegetable plaiting materials ($91.7 \%)$, Edible fruit and nuts $(-10.1 \%)$, Wine $(+137.2 \%)$, Copper ores $(+23.6 \%)$, Motor cars (+6.5\%), Ferro-alloys (-5.9\%) Beverages and spirits $(+44.3 \%)$.

\subsubsection{Diversification degree of export products}

Dependence of a nation on a limited number of commodities can trigger severe implications imposed by the trade shocks in terms of price instability of those commodities. As long as, developing countries are vulnerable to price instability of the exported commodities, measuring diversification degree of a country's export products is worth to be considered. In this regard, Georgia experiences a low degree of convergence with the world structure (See Table 4).

Table 4. Diversification Index of Georgian exports and number of exported products (2008-2017).

\begin{tabular}{|l|l|l|l|l|l|l|l|l|l|l|}
\hline Year & 20 & 20 & 20 & 20 & 20 & 20 & 20 & 20 & 20 & 20 \\
& 08 & 09 & 10 & 11 & 12 & 13 & 14 & 15 & 16 & 17 \\
\hline Diversificati & 0.7 & 0.6 & 0.6 & 0.7 & 0.7 & 0.6 & 0.7 & 0.6 & 0.6 & 0.6 \\
on Index & 4 & 9 & 9 & 1 & 0 & 9 & 0 & 4 & 7 & 5 \\
\hline Number of & 15 & 14 & 16 & 16 & 18 & 18 & 18 & 18 & 17 & 18 \\
Products & 2 & 2 & 0 & 6 & 4 & 0 & 3 & 4 & 8 & 7 \\
\hline
\end{tabular}

Although the number of total exported products increased significantly from 152 to 187, the value of the diversification index of Georgian export products did not change 
much. It experienced a slight decline from 0.74 to 0.65 , which is still high value (See Table 4).

\subsubsection{Export/Import trade intensity indices}

The EU share in Georgian export market is the smallest among other country groups (See Table 1) but holds the second place regarding the market size. The examination of the trade intensity by employing TI indices showed that the EU-Georgia bilateral trade relationship indicates a low-intensity pattern (See Table 5).

Table 5. Export/Import intensity indices (EII/III) of Georgia with the EU (20082017).

\begin{tabular}{|l|l|l|l|l|l|l|l|l|l|l|}
\hline Year & 20 & 20 & 20 & 20 & 20 & 20 & 20 & 20 & 20 & 20 \\
12 & 08 & 09 & 10 & 11 & 12 & 13 & 14 & 15 & 16 & 17 \\
\hline $\begin{array}{l}\text { EII of } \\
\text { Georgia with } \\
\text { EU }\end{array}$ & $\begin{array}{l}0.4 \\
8\end{array}$ & $\begin{array}{l}0.4 \\
5\end{array}$ & $\begin{array}{l}0.4 \\
3\end{array}$ & $\begin{array}{l}0.4 \\
7\end{array}$ & $\begin{array}{l}0.3 \\
9\end{array}$ & $\begin{array}{l}0.5 \\
4\end{array}$ & $\begin{array}{l}0.5 \\
5\end{array}$ & $\begin{array}{l}0.7 \\
3\end{array}$ & $\begin{array}{l}0.6 \\
4\end{array}$ & $\begin{array}{l}0.5 \\
8\end{array}$ \\
\hline $\begin{array}{l}\text { III of Georgia } \\
\text { with EU }\end{array}$ & 0.6 & 0.6 & 0.6 & 0.6 & 0.7 & 0.6 & 0.6 & 0.6 & 0.6 & 0.6 \\
5 & 1 & 4 & 9 & 5 & 9 & 5 & 5 & 6 & 1 \\
\hline
\end{tabular}

According to Table 5, the EI index slightly increased from 0.48 to 0.58 , and the II index does not experience noticeable changes.

\section{Findings and conclusion}

Since the very beginning, Georgia was the active player in international trade. In this regard, the geographical location of the country has a significant contribution. The natural endowment of being a trajectory between two giant markets prompts Georgia to evolve into the new mecca of international trade. In this regard, Georgian export performance indicates the positive tendency in many aspects, but still, there are a list of problems to be dealt with.

Within the last decade, Georgian exports increased by $54.66 \%$ along with overall trade turnover by $26.91 \%$. From 2011, Georgia has been exported over its mean value. The export share to GDP increased by $21.79 \%$. As for the export products, except the ferro-alloys, the value of all the major export commodities experienced dynamic increment. In addition, the study revealed the comparative advantage in 9 product categories, including top 5 Georgian export products. Together they account for $<60 \%>$ of total Georgian exports. Most importantly, except for Ferro-alloys, the aggregate demand of these commodities in the world and the EU area experienced inconsistent but still noticeable growth from 2007 till 2017. On the other hand, Georgian exports are not so promising if we look at the top 10 products (HS4) imported by the EU area and the world, which mostly consists of manufactured products like electronic machinery, vehicles, mechanical appliances, etc. These products require highly industrialized sectors but unfortunately, Georgia experiences a lack of technological modernization in this regard. However, convergence between Georgian and the EU/world import structures holds in terms of motor cars and 
pharmaceutical products. The low level of technological modernization can explain the modest performance of Georgian exports in the international market. Solution to this problem can be linked to the foreign direct investment (FDI), as it can enhance the capital accumulation in the export sectors with high growth potential and create positive externalities in terms of technology transfers and knowledge spillovers. Thus, directing the investment inflows in the most profitable export sectors can fill the gap between the actual performance of Georgian exports and its potential.

A bigger problem arose when the diversification index of Georgian export products was examined. Although the number of total exported products increased significantly, the value of the diversification index of export products remained high. As so, the low level of convergence with the world structure can cause the severe implications imposed by the trade shocks in the future. Therefore, stressing the importance of the export promotion policy changes, including the transparency of the accumulated export information. The accumulated experience of the exporting firms is the perfect guide for new entrants to become successful players and raise their chances to survive in a market. In fact, acquisition of this type of information is costly, thus, the local firms refuse to take the risk and expand their businesses to an unknown environment. For this reason, the flow of information should be organized through the state educational programs or by creating positive incentives for the exporting firms to share the experience. Currently, the Georgian government is running a similar program through the project of "Produce in Georgia" concerning export information transparency. The project grants Georgian producers to access the paid information provided by the top international research agencies, including "Euromonitor". In this regard, supporting local firms to transform into the exporters is an a priori for the diversification of the export products. Consequently, over a long period, Georgian export basket can be successfully diversified as the exporting firms will evolve through the Schumpeter's gale of creative destruction. Thus, Georgian exports will become more resistant to the trade shocks caused by the price instability of the commodities.

The significance of the main trade partners by country groups did not change much, except for the EU after the export embargos from Russia. Although Georgia experienced significant trade barriers imposed by Russia, it managed to diversify the export market to the EU through the DCFTA, which comprises reduction of the trade barriers to encourage the bilateral flow of goods and services. As a result, the value of exports to the EU doubled from 335.15 to 655.12 million USD. Apparently, the EU has the smallest share in Georgian export market and the level of the trade intensity is quite low. But, in accordance with the market size, the EU holds second place. In addition, the EU can be filtered as the new trade partner due to the ongoing process of Georgia's European integration, suggesting that there is much to trade between the parties. Thus, considering the market size of the EU and the unmatured trade intensity with Georgia evinces the importance of the region in the long-term perspective. On the other hand, reaping the maximum trade benefits from the EU market is not an 
easy task due to the significant difference between the Georgian export basket and the composition of the top imported products by the EU member states. Therefore, as we have already mentioned, to catch up with the trend of the highly demanded import products by the EU, it is necessary to direct the FDI inflow to the export sectors with high growth potential, which can accelerate the modernization of those sectors through the profound benefits of the FDI. As a result, Georgia will be able to produce those highly demanded products and gradually converge its export basket to the composition of the EU imports.

\section{References}

[1] Adarov A., P. Havlik (2016): Benefits and Costs of DCFTA, Evaluation of the Impact on Georgia, Moldova, and Ukraine. Bertelsmann Stiftung, the Vienna Institute for International Economic Studies (WIIW), Joint working paper.

[2] Balassa, B. (1965): Trade Liberalization and Revealed Comparative Advantage. The Manchester School, Volume 33, Issue 2. Pages 99-123.

[3] Bond M. E. (1987): An econometric study of primary commodity exports from developing country regions to the world. Staff Papers (IMF), Palgrave Macmillan Journals, Vol. 4, No. 2, pp. 191-227.

[4] Gogolashvili, K. (2017): EU-Georgia Relations, Future Perspectives. Georgian Center for Security and Development (GCSD), Policy Paper.

[5] Kawecka-Wyrzykowska, E. (2015): The EU-Georgia Association Agreement: AN Instrument to Support the Development of Georgia or Lip Service? Comparative Economic Research, Volume 18, Number 2.

[6] Kojima, K. (1964): The pattern of international trade among advanced countries. Hitotsubashi Journal of Economics, Volume 5, Number 1. Pages 1636.

[7] Liapis, P. (2011), "Changing Patterns of Trade in Processed Agricultural Products", OECD Food, Agriculture and Fisheries Papers, No. 47, OECD Publishing, Paris.

[8] Reyes. J., G. Varela, M. Mckenna (2014): Information for Export Survival: An Analysis of Georgian Export Performance and Survival in International Markets. Economic Premise, Number 151, The World Bank.

[9] Taralashvili, T., J. Kraciuk (2014): Foreign Trade of Georgian Agricultural Products and Existing Potential of Export to the European Union Market. Acta Scientiarum Polonorum. Oeconomia, Volume 13, Issue 1. Pages 123-134. 